DR. KAMAL ALSKAF (Orcid ID : 0000-0002-5477-8542)

Article type : Research Paper

\title{
The uptake of different tillage practices in England
}

K. Alskaf*, D. L. Sparkes, S. J. Mooney, S. Sjögersten \& P. Wilson

Division of Agricultural and Environmental Sciences, University of Nottingham, Sutton

Bonington Campus, College Road, Sutton Bonington, Loughborough, LE12 5RD, UK

*Corresponding author: email kamal.alskaf2@nottingham.ac.uk, kamal.alskaf@gmail.com

Running title: reduced and conventional deep tillage.

\section{Abstract}

Reduced tillage systems have been argued to provide several potential benefits to soil, environment and to farm incomes. In England, while many farms have partially adopted such practices, a large proportion of arable farmers do not undertake reduced tillage in any form. This paper analyses the rationale for and uptake of different cultivation techniques, including analysis of the barriers to adoption of reduced tillage, aiming to benefit policy makers and researchers and increase the spread of smart agricultural practices. Based on a postal questionnaire, we estimated that $47.6 \%$ of English arable land is cultivated using minimumtillage and $7 \%$ under no-tillage. As farm size increased, so did the probability of reduced

This article has been accepted for publication and undergone full peer review but has not been through the copyediting, typesetting, pagination and proofreading process, which may lead to differences between this version and the Version of Record. Please cite this article as doi: $10.1111 /$ sum. 12542

This article is protected by copyright. All rights reserved. 
tillage uptake. Furthermore, farms growing combinable crops were more likely to utilise reduced tillage approaches than other farm types. Soil type, weed control and weather conditions were noted as the main drivers for 'strategic' and 'rotational' ploughing, constraining continuous reduced tillage use. To effect greater reduced tillage uptake, greater communication between researchers and farmers is needed to facilitate the implementation of sustainable soil management solutions, supported by current legislation permitting responsible herbicide use in arable production. Financial support to access reduced tillage machinery may also be required for farmers operating smaller holdings. Adopting reduced tillage is a continuous learning process requiring ongoing training and information-gathering; supporting a network of reduced tillage 'farmer champions' would facilitate practical knowledge exchange, allow farmers to observe soil improvements, understand transition phase barriers, and ultimately encourage increased reduced tillage uptake.

Keywords: Reduced tillage, farm and farmer characteristics, farm size and type, soil management, agricultural policy.

\section{Introduction}

Tillage is primarily undertaken to provide conditions ideal for crop establishment and growth (Cannell, 1985). In the UK, conventional ploughing (PL) refers to inverting the seedbed and incorporating previous crop residues, typically followed by operations such as rolling and pressing (Carter et al., 2003). If the tillage system does not involve inverting the seedbed, it would be called "non-inversion tillage" or "reduced tillage" (Davies and Finney, 2002a). 
Tillage practices vary among farmers, regions and countries due to numerous factors. Farmers tend to choose the tillage system which best suits their range of cropping and soil conditions. Therefore, plough-based cultivations may take different forms depending on the depth of soil inversion, number of cultivation passes and machines used. Similarly, reduced tillage may take several forms depending on the intensity of the soil disturbance, amount of plant residues left on the soil surface and machines involved. For example, reduced tillage can be considered to be shallow reduced tillage, deep reduced tillage, strip tillage, or no tillage (Kassam et al., 2009; Carter, 2017).

The range of tillage practices commonly used makes tillage categorisation a complex process (Morris et al., 2010). To reduce definitional complexity of tillage systems, within this paper, we define 'reduced tillage' (RT) as referring to cultivation systems that do not involve soil inversion. This includes two-subsets of: 1) minimum-tillage (MT), which encompasses limited soil manipulation through mixing plant residues into the soil surface (Davies and Finney, 2002a) and; 2) no-tillage (NT) whereby crops are established directly into uncultivated soil, with or without removal of crop residues from the surface (Morris et al., 2010). For clarity, where ploughing is undertaken to any depth, this is classified as ploughed (PL).

\section{The importance of reduced tillage}

Timeliness of crop establishment is an important element of RT in the UK (Carter et al., 2003), as farmers have a narrow time window post crop harvest to establish the following crop (Morris et al., 2010). RT reduces cultivation time requirements compared to PL systems, facilitating a larger area of land to be sown within an optimum time window (Cannell, 1985; Lahmar, 2010; Kassam et al., 2012; Skaalsveen et al., 2019). RT potentially also facilitates the use of smaller tractors compared to PL (Bell, 2010) reducing fuel and machinery inputs. 
RT additionally offers many benefits to soil, including reduced soil erosion, enhanced moisture and organic matter retention, plus soil physical and chemical properties that can reduce soil greenhouse gas (GHG) emissions, all reducing the impact of agriculture on climate change (Holland, 2004; Morris et al., 2010; Mangalassery et al., 2015), albeit that some of these claims are contested in the literature (Powlson et al., 2014). Theoretically, the benefits cited should encourage farmers to adopt RT exclusively, or increase RT usage on farms where PL techniques are still used (Skaalsveen et al., 2019). However, RT adoption in some countries has been either slow or non-existent owing to a variety of reasons, including issues of soil type, machinery availability, climate conditions and a perceived loss of productivity (Farooq and Siddique, 2015). Many farmers are reluctant to move away from plough-based cultivation believing it is crucially important to combat weeds, being aware that over reliance on herbicides can lead to the development of herbicide resistant weeds, suggesting that as RT relies on herbicide use it should not be used exclusively (Heap, 2014; Heap and Duke, 2018). Reliance on plough-based cultivations might increase if glyphosate herbicide is banned. Ploughing is favoured by many farmers as it can produce higher crop yields and guarantees more consistent crop yield under extreme wet weather conditions (Giller et al., 2009; Alakukku et al., 2009). However, the main driver for UK farmers to adopt RT systems is primarily the potential to cultivate the largest available area at less cost (Morris et al., 2010).

Experience with tillage practices in Europe varies from country to country, and from region to region within a country. Investigating the differences between countries shows that farmers from the UK and Northern European countries have been pioneers in adopting RT practices, driven by concerns over costs, soil structure and erosion (Lahmar, 2010). The early work in the 1960s and 1970s, in The Netherlands, Germany and UK was very much driven by concerns over poor soil structure, especially following wet harvesting conditions. Farmers in 
Mediterranean European countries are primarily driven by water and soil conservation, reduced seed drilling equipment costs, and effective herbicides in Italy (De Vita et al., 2007); in France the main driver of RT uptake is to reduce labour and other cultivation costs (Lahmar, 2010).

\section{The pattern of RT uptake in the UK and Northern Europe over time}

$\mathrm{RT}$ in the UK is not a new approach. In the 1970 s, around $35 \%$ of crops were established under RT, but this proportion declined to $25 \%$ in 1988 due to increasing weed problems associated with RT (Davies and Finney, 2002a). Carter (1994) noted that residues left on the soil surface can interfere with the seed drilling process and increase disease and pest burdens, reducing RT uptake. The use of PL also increased after the 1993 straw burning ban in England and Wales (Townsend et al., 2016).

According to the Farm Practices Survey 2010 of the Department for Environment, Food and Rural Affairs (Defra), 40\% of the arable land in England was established under MT (with at least $30 \%$ of stubble and crop residue left on surface) whereas only $4 \%$ under NT where all stubble was left on the soil surface (Defra, 2010). These data were collected from farmers by a structured postal survey sent to 16,500 farmers and the response rate was around $65 \%$. The Survey on Agricultural Production Methods (SAPM) in 2010 showed that RT (MT and NT) was used on $39 \%$ of UK arable land, in comparison to $26 \%$ in Europe; NT was estimated to be $5 \%$ in the UK, greater than the $1 \%$ in Germany and $4 \%$ in France (EuroStat, 2013).

Overall, these data show that the majority of arable land in the UK and Northern Europe is cultivated using PL system. This is an indication that RT uptake by farmers is slow in most European countries. These studies do not consider the use of occasional plough-based cultivations that farmers may undertake every few years while also using RT. This flexible 
approach to cultivations could create differences in the estimated RT uptake between survey years.

In the UK, RT uptake is restricted by soil type and its effects on soil compaction (Cannell, 1985, Davies and Finney; 2002a, Morris et al.; 2010). Powlson et al. (2012) noted that NT is adopted in the UK, where the predominant soil type is calcareous clay only, which facilitates the creation of good tilth on uncropped land, making direct seeding more successful. Calcareous soils can mitigate compaction as a result of good drainage, self-mulching and stable soil structure (Davies and Finney, 2002a; Soane et al., 2012). In Northern Europe, Melander et al. (2013) observed that RT is challenged by an enormous increase in weed population, such as blackgrass (Alopecurus myosuroides Huds.). Therefore, Lutman et al. (2013) noted that PL is necessary to combat weeds. To utilise RT and mitigate weeds, some farmers tend to plough their land every few years (3-4 years), referred to as rotational ploughing (Powlson et al., 2012). Extending this concept, Townsend et al. (2016) defined an occasional PL practice used in response to unfavourable weather conditions or weed problem as "strategic tillage". In this case, farmers would typically have both PL and RT systems on their farms and this provides them with a "mixed tillage" system.

\section{Reduced tillage and crop yields}

Data on the effects of RT on crop yields have been contradictory with both negative and positive effects of RT previously recorded (Van den Putte et al., 2010, Arvidsson et al., 2014). This effect varies according to crop type, rotation and tillage depth. In individual field studies such as Knight (2004) and Verch et al. (2009), it was reported that higher yields were recorded under RT compared to PL. However, tillage studies are limited, with many related to the period before the straw burning ban was implemented. Under these conditions, diseases, weeds and pests would have a smaller negative impact on the following crop 
(Graham et al., 1986), and hence it is argued that these previous studies do not reflect the current situation of the effects of RT practices on crop yield, and the potential future use of RT, should a ban on glyphosate occur. Contemporary RT machinery operations are also more advanced, providing quicker work rates in comparison to those of the 1980s, facilitating prompt soil preparation work within a suitable time window that benefits crop growth. Consequently, this improved crop establishment may lead to greater yields (relative to plough-based systems) than those achieved in the 1980s (Townsend et al., 2016). Further studies are needed to assess the current situation.

\section{Factors that affect adoption}

The importance of social drivers in uptake of agricultural innovation have been previously noted, in particular with respect to the complexities of RT uptake (Bitsch, 2005). Pannell et al. (2006) argues that these factors need to be included in extension advice programmes. Previous studies have also shown the importance of social aspects in on-farm practice adoption (e.g. Bultena and Hoiberg (1983), Nowak (1992), Roling and Wagemakers (2000), Eckert and Bell (2005), Bell (2010)). Others have noted the major challenges involved in RT uptake (e.g. Coughenour and Chamala, 2007) and that adoption of RT requires farm managers to learn how to overcome challenges, such as weed management and fertiliser incorporation (Bultena and Hoiberg, 1983).

According to one meta-analysis exploring the adoption of different best management practices, it was found that education level, farm size and other information such as capital, income, positive environmental attitude and environmental awareness are influencing factors (Prokopy et al., 2008). Farmer attributes, including age and education, and farm characteristics, particularly type and size, varied between adopters and non-adopters 
(Pimentel et al., 1995, Ingram, 2010, Bossange et al., 2016, Hydbom et al., 2018, Marr and Howley, 2019).

Typically, farmers do not adopt different best management practices at the same pace. Vanclay (2004) and Pannell et al. (2011) have recognised that farmers are quicker at adopting less complex innovations than more complex ones. RT forms are considered complex practices as they require an extensive change in farm management. This could be attributed to the fact that RT outcomes are based on farm-specific experiences of farmers, which may not be disseminated sufficiently to others, as farmers view their own circumstances to be specific. Each farmer will adjust the RT practices they follow based on the local context (i.e. the crop varieties and types, machine availability, location, soil type and land topography). In contrast to Rogers' model of innovation diffusion theory (Rogers, 1961), uptake of multifaceted and complex agricultural innovations cannot be easily predicted, owing to the many variables influencing farmer decision in the case of the RT. These variables influencing uptake include aspects involved in the process of adoption, such as the communication channels and the facilitation of ideas exchange, as well as the individual context and interpretation by the farmer. Therefore, adoption of RT practices is complicated compared to the adoption of other, arguably simpler, agricultural innovations. Thus, any successful extension work and innovation delivery would have to encompass these wider social and economic processes (Fleming and Vanclay, 2009; Ingram, 2010; Wauters and Mathijs, 2014). The adoption of new techniques into a farm business is in part based on farmer understanding of the techniques; understanding farmer perspectives and challenges therefore represents an important area of study for generating incentives to transition from traditional ploughing to RT. 
Given the potential and observed yield, timeliness of operation and cost savings advantages from RT identified above, this study hypothesised that RT is undertaken by UK farmers to a limited extent and is conditional upon farm structural and farmer biographical factors. In testing this hypothesis, this paper aims to: a) determine the extent of adoption of RT (NT and MT) in commercial agriculture in England, b) understand the farm or farm-level factors affecting farmer uptake of RT, and c) assess the challenges faced by commercial farmers in the uptake of RT.

\section{Methods}

To maximise the response rate compared to other research methods such as interviews and focus groups, a postal survey was sent to 2000 English farmers with pre-paid returnaddressed envelopes (Dillman et al., 2011). The questionnaire had been previously piloted on 12 respondents and subsequently modified. The questionnaire was sent out in January 2016 as farmers were expected to be less busy with their practical agricultural activities at this time of year. The addresses of farmers were supplied by Experian, whose database is built from the 'Yellow Pages Directory', which provided addresses within the Business Activity class 'Farmers', and from the Thompson Directory within the Business Activity class 'Farming Crops'. The only information provided about these farmers is the business activity. Limited information is included in these directories; therefore, it was not possible to target farmers according to their specific agricultural practices. Respondents were not asked to provide their contact details, to reduce barriers to completion of the survey, hence removing the potential for contacting farmers that did not respond to the survey and for any follow-up communication. In addition, to further encourage survey completion by reducing barriers to participation, farmers were not asked to provide any financial data. 
Recognising the challenge of potential response bias, the covering letter clearly stated that the survey was to explore tillage practices in general and not just RT approaches (further details on the survey options are provided in Supplementary Material 1). A number of processes were followed in the questionnaire design to avoid bias, such as avoid leading questions, include the use of interval questions, provide a simple set of answer options, use precise and simple language, with no mention of company names or acronyms (Dillman et al., 2014). Structurally, within the questionnaire, respondents who only undertook PL techniques were directed to specific pages of the questionnaire. This might have encouraged farmers who did not use RT to participate in the survey. According to the Farm Business Survey (2018), there are estimated to be 56,744 commercial farm holdings in England. Therefore, the sample of 2,000 registered farm holdings represents approximately $3.52 \%$ of the farms in these regions. This percentage of responses is considered representative of the farming population as per recent studies (e.g. Townsend et al., 2016; Bossange et al., 2016).

Based on the huge body of literature provided above on the role of farm and farmer characteristics on RT adoption (e.g. Bossange et al., 2016; Townsend et al. 2016), this questionnaire explored farm data, including land holding size, farm type, location (county) and the Governmental Office Region (GOR) in which each farm was located. GORs are used for statistical purposes by the UK government and the European Union. The use of the GOR data in this paper facilitates comparison with the literature and comparable data provided by the different research sources, e.g. the Farm Business Survey. The GOR potentially provides a broad indication of the effect of the location and weather conditions on RT adoption. The questionnaire captured age, gender, highest education qualification and years of experience in managing the farm enterprise of respondents. Respondents were asked to note which tillage technique(s) they used on their farm and the proportional area of their land that they plough or cultivate through RT. RT area was calculated by adding the areas NT and MT. Another 
section captured data on the barriers towards adoption of NT and MT. For most questions, closed questions, with pre-determined possible responses for respondents to choose from, were used, specifically; farm size and location; and farmer age, experience, gender and educational qualification were captured through closed question formats. The closed question method has been successfully followed in a number of recent studies (e.g. Wilson et al., 2014) enabling large numbers of respondents to complete similar questionnaires or surveys. This approach reduced the time required by farmers to complete the survey, and facilitated data collation from a large number of respondents within a short period of time. The proportions of arable area cultivated by NT, MT or PL were captured by percentage grouping categories. Experience of using NT and MT were captured through four different closed question categories about length of experience, with farmer knowledge and experience of using NT and MT, together with barriers towards the use of NT and MT, also being captured through closed question approaches. Additional space was also provided after each question for respondents to add other factors influencing their decision on tillage practice and provide ease of data entry for the respondent, as well as providing the facility and option for additional comments. For questions which needed importance ratings, a Likert scale was provided: specifically these included questions relating to the importance of factors that determine cultivation decisions, farmer perceived knowledge of NT/MT techniques, and motivations towards starting or increasing the use of NT on their farm. The covering letter and the questionnaire are provided in Supplementary Material 2.

\section{Survey responses}

By the end of April 2016, 479 replies (24\% return rate) were received providing 371 usable responses for analysis, which constitute $0.65 \%$ of the commercial farm holdings in England.

The remaining responses (108) were discarded as they were: incomplete, respondents declined to answer surveys, from respondents who had retired, and from livestock farmers 
who did not undertake any tillage practice. The responses were categorised based on: prominent tillage system used; farm size; farm type; age; education level of the farmer; region in which the farm was located. Where respondents chose not to answer a question, this was defined as "unknown". If the respondent did not answer the questions in relation to the tillage systems, the questionnaire was excluded from the analysis. Comparing our responses to commercial farms in England by farm type and Government Office Region (GOR), shows that we achieved $65 \%$ and $70 \%$ correlation against population statistics respectively.

\section{Statistical analysis}

The respondents were categorised on the basis of whether or not they were using RT to undertake non-parametric hypothesis testing and analyse the probability of uptake via logistics regression analysis. Using Chi-squared tests, responses were analysed to test the hypotheses that there was no significant relationship between undertaking specific tillage practices and farm or farmer characteristics.

Responders were categorised as RT adopters and RT non-adopters; an adopter was defined as a respondent using RT to any extent (e.g. a small percentage of cultivated area to $100 \%$ of the cultivated area), and a non-adopter was defined as a respondent using PL only. Making changes to tillage practice may be influenced by farmer perception of new technologies or techniques (Pimentel et al., 1995; Ingram, 2010; Bossange et al., 2016; Hydbom et al., 2018; Marr and Howley, 2019). It was hypothesised here that both farmer and farm characteristics may influence RT uptake, such as:

$$
P(R T)=F(A, B, C, D, E, F, G, H)
$$


$\mathrm{P}(\mathrm{RT})$ : denote the farmer has adopted RT (1) or not (0).
A: Farm size.
B: Government Office Region (GOR).
C: Farm type.
D: Farm tenure.
E: Age (year).
F: Minimum experience (year).
G: Gender.
H: Highest education level.

To predict the likelihood of RT adoption a logistic regression model was used to explore the relationship between the dependent dichotomous variable RT and one or more nominal independent variables. The STATA (v14) statistical package was used. As a cumulative logistic probability function is assumed in the logit regression, the model can be described as:

$$
\mathbf{P}(\mathbf{R T})=\frac{1}{1+\mathrm{e}^{-\int(\mathrm{A}, \mathrm{B}, \mathrm{C}, \mathrm{D}, \mathrm{E}, \mathrm{F}, \mathrm{G}, \mathrm{H})}}
$$

$\mathrm{P}(\mathrm{RT})$ the probability of RT adoption. The variables of the farmers and the farm data are described by a vector of variables.

The odds ratio (OR) is the measure of the effect of the dependent variables; farmer and farm characteristics, on the independent variable $\mathrm{P}(\mathrm{RT})$. It is used to compare between the effects of the different categories for each variable given a one unit change in the variable (e.g. from the reference farm type group of RT adopters to another farm type group).

To assess the multi-variable model, the Wald test was used to examine if each variable should be included in the model (Bewick et al., 2005). The goodness of model fit was tested using the likelihood ratio (LR) (Agresti and Kateri, 2011). The coefficient of determination 
(Nagelkerke, Cragg \& Uhler's $\mathrm{R}^{2}$ ) was used to check how well the model represented the data (Greene, 2000, Bewick et al., 2005).

\section{Results}

Proportion of farms using NT, MT and PL

Only two farmers $(<1 \%)$ adopted NT on all their arable land but $17.25 \%$ of the respondents applied NT on part of the area; $15.14 \%$ were using NT on $50 \%$ or less of their area, and $11.36 \%$ were using NT on less than $30 \%$ of the cultivated area on their holdings.

MT was adopted on all the arable land of $7.28 \%$ of respondents and $64.86 \%$ adopted MT on some of their land (from 10 to $90 \%$ of the farm area).

No form of RT was used by $30.73 \%$ of respondents and hence used PL. Thus, $69.27 \%$ of respondents adopted at least one kind of RT practice (NT or MT) (Table 1, Figure. 1, A).

\section{The agricultural area under NT, MT and PL}

The total area of land farmed by the respondents was 118,713 ha which represents $2.64 \%$ of the total UK arable crop area, which was 4,505,000 ha in 2015 (https://www.gov.uk/government/uploads/system/uploads/attachment_data/file/486326/struct ure-jun2015final-uk-17dec15.pdf Page 11.). The area of respondent land under NT was estimated to be $8,238.5$ ha $(7.04 \%)$, area under MT was 55,747 ha (47.61\%), with the area under PL being 53,101 ha (44.35\%) (Figure. 1, B).

\section{Factors associated with the adoption of reduced tillage in England}

Farm size. Farm size ranged from 6.7 ha to 5,000 ha. Around $75 \%$ of the respondents were managing more than 100 ha (Figure. 2, A). Adoption of RT was significantly different across farm size groups (Chi-Squared test; $P<0.001$, Figure. 2, B); e.g. $97.26 \%$ of respondents who farm more than 400 ha have adopted RT partially or completely on the farm, while RT is 
used on $31.82 \%$ of farms with less than 50 ha (Table 2). On farms greater than 200 ha (the average farm size in England), $62.8 \%$ of respondents undertook RT.

Farm type. Farm types included combinable cropping, general cropping, mixed (crops and livestock) or livestock farmers. The majority of respondents $(44.57 \%)$ were managing mixed farms of combinable crops and livestock. Only 5.43\% of the respondents using RT were solely livestock farmers (Figure. 2 C). Farm type had a significant effect on the tillage practices in the farm (Chi-Squared test; $P<0.001)$ (Table 2). Farmers who managed combinable crops adopted RT to the greatest extent $(81.89 \%)$. On general cropping and mixed farms, RT was adopted to a lesser extent than on farms focussed on combinable crop, but to a greater extent than for livestock farms (Figure. 2, D).

Government Office Regions (GOR) and European Union Super Regions. Less than one quarter (23.2\%) of respondents were from East of England GOR and over one-half $(51.93 \%)$ were from the wider East EU region (Figure. 3, A, B). RT adoption was not consistent across GORs or EU regions (Figure. 3, C, D). In East of England, South East and South West GOR, the number of farms using RT practices was significantly greater (Chi-Squared test; $P<0.05$ ) than all other GORs. Examining the EU regions showed RT adoption to vary between the regions (Chi-Squared test; $P<0.001)$. There was greater RT adoption in the East $(59.92 \%)$ compared with that in the West $(17.86 \%)$ or the North $(22.22 \%)$ (Table 2$)$.

Farmer age. The age of the respondents ranged from 18 years-old to more than 75 years-old; $87.43 \%$ were 45 years or older (Figure. 4, A). The differences between the age groups were not statistically significant (Chi-Squared test; $P=0.19$, Table 2), however, there was a slight trend for farmers aged less than 45 years to be more likely to adopt RT, with more than $80 \%$ of this age group using at least one form of RT. Farmers who were more than 64 years-old were the least likely to adopt RT (60\%) (Figure. 4, B). 
Education. With respect to education level, around $80 \%$ of the respondents did not have a university degree (Figure. 4, C). The adoption of RT was observed to be greater for respondents who had undertaken higher education $(P<0.001)$ (Figure. 4, D); among respondents who have Masters or PhD degrees, adoption of RT was greater than $80 \%$. RT was adopted by $54.23 \%$ of respondents with General Certificate of Secondary Education (GCSE) or A-level as their highest level of academic qualification (Table 2).

\section{The logistic model results}

The null hypothesis of the logistic regression test was that all factors had the same effect on RT adoption. The number of observations used in the descriptive statistics and chi-squared analysis was 371 respondents. However, in the logistic regression analysis, 36 responses were excluded because of not being fully completed across all categories. A summary of the logistic regression data is provided in Table 3.

The model showed that RT adoption was significantly influenced by farm size and farm type $(P<0.001$, Table 4$)$. Overall $29 \%$ of the variation in the model was explained by these two variables. Farm size had a positive impact on RT adoption. The reference farm size was 50 ha (odds ratio $(\mathrm{OR})=1$ ). The $\mathrm{OR}$ for the category $50-100$ ha was 1.22 , but, this was not significantly different from the reference farm size group $(P=0.7)$. However, for the larger size farms significant differences were observed: category $100-200$ ha $(\mathrm{OR}=3.35 ; P=0.05)$; category 200-400 ha $(\mathrm{OR}=9.42 ; P<0.001)$; category $>400$ ha $(\mathrm{OR}=47.04 ; P<0.001)$. However, for farms with $>100$ ha, the likelihood of RT adoption was significantly greater than for farms of $<50$ ha. As farm size increased so did the likelihood of RT adoption, and in particular for the largest farm size category (>400 ha). 
A further important factor in the adoption of RT was found to be farm Type (Table 4). The reference group $(\mathrm{OR}=1)$ was farms focussed on combinable crops. Mixed farms returns an OR of $0.4(P<0.05)$; general cropping farms had an OR of $0.38(P=0.05)$, and livestock farms had an OR of $0.09(P<0.05)$. Thus, the OR values show that RT is more likely to be adopted on farms growing combinable crop, as the OR for the other farm types is less than unity in each case and significantly different from the reference group.

In this logistic regression model, the remaining variables - gender, age, GOR, education, were found not to have a significant impact on adoption of RT. But, it is informative to note that there is a correlation between farm size and other factors. For example, $41.67 \%$ of respondents who have been awarded a Master's degree are farming between 200-400 ha and a further $41.67 \%$ of respondents with the same degree are managing more than 400 ha farms. By contrast, only $6.02 \%$ of the respondents who achieved GCSE or A-level as their highest educational qualification are managing more than 400 ha. Typically, respondents who operate large farms are more likely to be located in the East England EU region and to be of Combinable Crop Farm Type. Hence, level of education and location may be important but masked by farm size and type classifications (Supplementary Material 3).

From the logistic model, neither farmer age nor years of experience have a significant effect on RT uptake. The reference age group was "less than 34 years-old" (OR=1). The age category 35-44 was observed to have the greatest likelihood of RT adoption $(\mathrm{OR}=1.16$; $P=0.9)$, with the least likely being the $65-74$ years-old group $(\mathrm{OR}=0.38 ; P=0.43)$. As anticipated, given the link between age and experience, farmer experience did not show a significant impact on RT uptake. The OR for farmers with 20-30 and 30-40 years of experience, were, respectively 1.38 and 1.25 , but these were not significantly different from the reference group (less than 10-year experience). 
With logistic regressions, $\mathrm{R}^{2}$ is less likely to reach the value of 1 due to using the odds ratio as the basis of calculation (Cohen et al., 2013). The Nagelkerke, Cragg \& Uhler's $\mathrm{R}^{2}$ was 0.42 , a value that represents a good model fit. The Wald test indicated that the effects of farm size and type were significant $(P<0.05$, Table 4$)$. As the LR test value was less than 0.05 (a significant result indicates poor prediction), the null hypothesis is rejected indicating that the model does fit the data (Engle, 1984, Agresti, 2002, Bewick et al., 2005).

\section{Factors which influence farmer tillage system decision making}

RT adopters (who have undertaken RT totally or partially on their farm) cited a range of reasons for undertaking conventional ploughing from time to time. Farmers were asked to evaluate the factors listed in Table 5 on a Likert scale according to their importance. Prominent soil type had a substantial influence among the respondents, with $72.25 \%$ noting that their tillage decision was soil type dependent. Some respondents noted that soil type varied across the farm and consequentially an RT system would not suit the whole farm. Notably, many of the respondents additionally cited in the free text comments that prominent soil type was an influencing factor, noting that in a wet year, ploughing heavy clay soil is a necessity to help in drainage.

Weed management was cited as the second most challenging factor with respect to RT uptake in the long-term. Two-thirds $(62.78 \%)$ of respondents noted that weed management was a factor in their tillage choice. The third most cited reason was the weather, with respondents tending to plough intensively in wet years, aiming to improve soil drainage. Labour availability was cited by $44.12 \%$ of the respondents. Climate change mitigation options were cited by only $9.02 \%$ of respondents who considered these as an important factor. 


\section{Barriers to the adoption of $R T$}

Respondents who are still undertaking PL, but have experienced or are still practising one or more of RT forms mentioned several difficulties to each one of NT and MT as reported below.

The challenges of undertaking MT (RT excluding NT). Figure. 5. A presents an ordered list of the challenges of practising MT as revealed in the survey. Weed burden was the main challenge, cited by $42.68 \%$ of the respondents who were still undertaking PL to any extent (314 respondents). Slugs were the second most cited challenge (28.03\%). Other challenges included untidy fields, poor crop establishment, lower yields and more crop diseases; however, these factors were cited less frequently than those relating to weeds and slugs. Respondents were invited to cite other challenges (these are listed in Supplementary Material 4).

The challenges of undertaking NT (RT excluding MT). The most common problems of NT adoption mentioned by $25.16 \%$ of the respondents who were still undertaking PL to any extent (314 respondents) was the increase in the population of the slugs and weed control (24.84\%). Poor crop establishment was listed as the third common problem, followed by top soil compaction Figure. 5. B. Respondents added further comments as shown in Supplementary Material 5.

\section{Learning about the techniques of reduced tillage (NT/MT)}

Most respondents (65\%) who have undertaken any form of RT, stated that they had learned about it by "self-experimenting", while $56 \%$ of those RT adopters, mentioned that they had been informed about RT by other farmers and advisers (e.g. neighbours, agronomists, consultants). Other sources e.g. including the farming press, cereals event, companies, organisations, internet, social media, TV programmes have been reported by fewer farmers as 
influencing factors. In the space provided on the questionnaire for further comments, respondents mentioned "field and machine demonstration" across all source of learning as a positive factor affecting the RT uptake.

\section{Factors that have prevented farmers from adopting reduced tillage}

Respondents who were still undertaking PL to any extent (314 respondents) were asked about factors preventing them from adopting RT on their farms (respondents were asked to tick as many as applied for this question). The most frequent answers were 1) the satisfaction with the current production (37.6\%) and 2) to control black grass and other weeds $(37.3 \%)$. Concerns about machines, slugs and reduced yield seem to have been of less critical importance for the respondents as $27.4 \%, 24.5 \%$ and $22.6 \%$ respondents respectively cited them. Other factors such as untidy perceived field appearance, lack of government support for these techniques, advised against RT by other farmers or advisers, and lack of information were mentioned less frequently.

\section{Stop ploughing and start or increase the use of reduced tillage}

Respondents who were still undertaking PL to any extent (314 respondents) were also asked about incentives that would persuade them to start or increase RT. The most frequent answer cited was the availability of the machines $(28.66 \%)$. The second most frequently noted answer was the introduction of government incentives (e.g. grants for machinery) as $21.97 \%$ of the respondents cited this option. Other incentives such as "more information", "specialist contractor", "training on practices" were cited less frequently.

\section{Discussion}

\section{Arable land area under $R T$ practices}

Typically, the estimated area cultivated under RT varies between studies. The present study estimates that $54.56 \%$ of the land in England is cultivated under RT (47.61\% under MT and 
7.04\% under NT), based on the arable land area managed by the respondents and the percentage area cultivated under different techniques as noted by the respondents. By contrast, the area under RT was estimated by the Department for Environment, Food \& Rural Affairs as $44 \%$ (Defra, 2010), using a structured survey sent to approximately 16,500 holdings. The overall response rate was $65 \%$. A smaller estimate of $32 \%$ reported in a recent study by Townsend et al. (2016), who surveyed 249 farmers, argued that Defra's estimate was potentially based on farmer responses biased towards those interested in RT. Additionally, our results are broadly in line with recent evidence that only $8.27 \%$ of the UK arable land [England specific data is not available] is under NT as reported by the European Conservation Agriculture Federation (ECAF, 2017). The variation in RT area between the different studies could be attributed to the usual rotational and strategic ploughing decisions in different years that may alter the total area under RT over time. It could also be that the majority of farmers do not accept the dichotomy concept of a single "tillage practice", as noted by Townsend et al. (2016), due to the need to make strategic cultivation practice decisions to mitigate soil compaction concerns. Overall, comparing between the results of our current study and with findings from previous research, we are not able to present conclusive evidence whether RT adoption is increasing or decreasing over time.

\section{Bias in the results}

This current research presents results based on a postal approach. This method has been criticised in the past by Pennings et al. (2002) who argued that only people who were interested in the subject would respond. Survey bias is possible in all survey studies, including the present one where the correlation of survey sample returns against population data of $65-70 \%$ indicates that our response was biased towards respondents farming larger areas. As more than $75 \%$ of the respondents were managing 100 ha or greater, and more than $50 \%$ of the respondents were managing more than 200 ha (the average area of arable farms in 
England), we acknowledge that our sample could be biased towards large and commercial farms. This does not mean that these results are unrepresentative of the farm area in England however, and arguably may more appropriately represent tillage practices by total arable area. This issue has been previously noted within the literature representing survey response results; specifically, the method of depending on business directories has been used in many similar studies (e.g. Morris et al., 2000; Carter, 2001; Mattison and Norris, 2007; Lobley and Butler, 2010; Townsend et al., 2018), a number of whom note that such survey approaches tend to more accurately reflect results by total land area, rather than being representative of the population of farmers. In addition, our survey was specifically designed to capture practices and attitudes towards tillage techniques in the broadest sense, with internal questionnaire sign-posting facilitating completion and return of questionnaire responses from farmers using a range of tillage techniques. Overall, having a large number of respondents who are not undertaking RT, and including respondents that have declared that they are not planning to change their current tillage polices, indicates that this study is arguably less likely to be biased towards farmers practicing RT, and thus is representative of overall farmer attitudes towards RT.

\section{Factors associated with RT adoption.}

This study supports the results of two contemporary reports, EuroStat (2013), whose data are collected from national bodies such as Defra, and Townsend et al. (2016), who concluded that RT is more frequently adopted on larger farms for several reasons. First, timeliness is more crucial on large farms (Melander et al., 2013). Time required for crop establishment can be reduced using RT practices. Consequently, farmers could complete the field preparation in a relatively shorter time compared to PL (Carter et al., 2003). Second, to some extent RT adoption is still in the experimentation phase for many farmers. Consequently, managers of large farms are more likely to be able to take the risk of trying new practices on their farms. 
Managers of small farms may not be willing, or able, to bear the potential reduction in yield in the first one or two years of the transition to RT whereas managers of larger farms may be better able to compensate losses, if occurred, from other crops (Lahmar, 2010). Third, large farms would be able to provide the funding required to purchase the machines needed for RT. Managers of large farms are likely to more promptly take on technologies as they are able to spread the cost over a greater land area. Expensive cutting-edge technologies take more time to become established on smaller farms; for instance, in the United States, high cost of machines were considered a barrier to RT uptake, although such innovations would allow them to expand their farms (Lambert et al., 2012). By contrast, the adoption of the low cost innovation such as improved seed is much quicker on smaller farms (Krause and Black, 1995; Swinton et al., 2015). Forth, it is more feasible for large farms to own or have access to a larger range of machines than for smaller farms; hence large farms can own both machines for RT and PL, whereas small farms are less likely to have the financial ability or the space to hold a range of tillage machines at the same time (Townsend et al., 2016). The results of our study did not show that machine affordability was an independent factor influencing RT adoption; however, as agricultural machinery has typically increased in size, complexity and cost over time, it is argued here, and, as noted previously (Townsend et al., 2016), that small farm size will, in part, act as a barrier to machinery investment.

The present study shows that RT is adopted predominantly on farms only growing combinable crop compared to general cropping and mixed crop farms. This result accords with Townsend et al. (2016) and Bossange et al. (2016) who believed that this result flows from the diversity of the crops grown on mixed crop farms as different crops have different tillage and drilling requirements. This creates a burden on farmers to spend more money owning the range of required machines as well as more time to learn the best practice for 
every crop, albeit some crops might benefit from RT to a greater extent than other crops on the same farm.

It has been previously observed that there is greater potential of RT uptake in the East of England region (Cannell, 1985). Our results confirmed that RT is now relatively popular with farmers in that region $(\sim 60 \%)$, but it is not an independent influencing factor. Two main factors associated with greater RT uptake were large farm size and combinable-cropping activities; the region within which the farm is located was not, in itself, identified as a significant driver of RT uptake although farms in the East of England tend to be larger than other regions. While education, age and experience have an important role on the adoption of the new agricultural innovation (Han et al., 2018; Marr and Howley, 2019), this study did not find that they did not have an independent impact on RT adoption. Thus it is more likely that these factors were masked by other factors such as farm type and size.

Soil type is more likely to be the main factor governing the initial farmer decision to undertake RT (Cannell, 1985; Davies and Finney, 2002b; Davies and Finney, 2002a; Morris et al., 2010). However, this study did not identify which soil type is best suited for RT. In agreement with the review by Morris et al. (2010), this study shows that RT adoption is restricted by increased weed populations. From a weed management perspective, ploughing is essential to bury the weed seeds down in the soil, thereby stagnating their growth (FroudWilliams et al., 1983a, Froud-Williams et al., 1983b, Froud-Williams et al., 1984) instead of relying on costly herbicides, to which resistance of weeds may increase over time in addition to their effects on the environmental (Moss et al., 2007). However, Bullock (2004) found that weed burden can be minimised by following crop rotations and having stale seedbeds. In support of Davies and Finney (2002a), the current study found that slugs are a main concern for RT adopters. This issue was found more serious with NT as larger stubble amounts are 
left on the soil surface compared to MT (Bailey and Duczek, 1996, Conway, 1996, El Titi, 2002).

Our results demonstrate that RT has not been widely adopted by English farmers. It is evident that a considerable level of uncertainty exists in relation to RT adoption as an agricultural innovation. When farmers become well-informed about this technology and how to overcome the difficulties, uncertainty may diminish. Therefore, the provision of relevant information to farmers may, in conjunction with making their own changes which suit the conditions on their farms (Coughenour and Chamala, 2007), increase RT uptake.

Our data shows that farmers tend to learn about RT by self-experimenting and from others; mainly neighbours, contractors and agronomists. This highlights the importance of knowledge exchange and better communication between researchers and farmer groups in areas and regions where RT is less adopted. This may allow scientists and advisers to propose solutions to weeds and compaction problems from RT, from improving resistant crop varieties or growing certain crops. More active visits to fields and on-farm demonstrations where NT has been successfully undertaken are recommended, as successful stories of innovative farmers, can encourage other farmers (Ingram et al., 2016, Pappa et al., 2018). While there is a rapid increase in social media prevalence, our findings showed that farmers do not depend on this channel of communication to obtain RT information, therefore, in contrast to findings by Mills et al. (2019), social media does not currently seem to be an effective way to communicate with farmers or inform their decision-making in relation to tillage choice.

Costly machinery requirement for RT was mentioned by respondents but not ranked as a main RT uptake constraint. This suggests that an important consideration should be given for farmers to gain access to RT machinery at reasonable cost. Long-term loans and/or financial 
governmental support are suggested in order to enable smaller farmers to purchase those machines. Another option could be by supporting machinery ring associations. Equally, as RT is undertaken to a lower extent on farms where cereals are not the main crops; such as vegetable and root crop farms, it is recommended that more research and experimental work be conducted to explore the effects of best RT practices on these crops under the UK conditions, as only a few studies, such as Derpsch and Friedrich (2009) (reviewed in Kassam et al. (2018)) reported that RT guarantees production of these crops in various environments. RT adoption is a dynamic and a multifaceted process that requires continuous update and demonstration (Feder and Umali, 1993). The respondents of this study highlighted the role of the on-farm demonstration, organised by farming organisations, and also by learning from other farmers. Therefore, establishing benchmark fields, where farmers can observe soil and crop improvements achieved through RT, could assist in spreading this knowledge.

\section{Conclusions}

This paper has presented a contemporary evidence base for RT adoption and explored the effects of farm and farmer characteristics on RT uptake. The probability of RT adoption in England increases with the increase in farm size. It is also noted that RT is more highly adopted on farms growing combinable crops compared to other farm types. RT uptake does not seem to be influenced by personal characteristics of farmers. Prominent soil type is a main driver of tillage choice. Weeds and slugs were additionally identified as main challenges to RT adopters. To increase RT adoption, farmers will need to be better informed about using crop rotations, managing plant residues and provided with appropriate policy and regulatory signals to encourage RT uptake and achieve sustainable intensification outcomes. More improved herbicides are needed, and a legislation change for farmers to use effective chemicals is required (Melander et al., 2013). Long rotations on the same farm could be a method for reducing tillage frequency and combating weeds as crop rotations prevent the 
build-up of the pathogens and pests when one crop is grown frequently (Townsend et al., 2016). Strategic and rotational ploughing were observed to overcome these constraints. A glyphosate ban might make farmers more dependent on ploughing to mitigate weeds. This paper provides crucial evidence of the challenges and barriers that farmers face in relation to RT uptake. Contemporary policy design combined with traditional and innovative mediabased knowledge transfer opportunities arguably offer the best possibilities of increasing RT uptake in England and to serve as a model for advancing RT uptake across Northern Europe.

\section{References}

A. KASSAM, FRIEDRICH, T. \& DERPSCH, R. 2018. Global spread of Conservation Agriculture. International Journal of Environmental Studies.

AGRESTI, A. 2002. Categorical data analysis, Wiley New York:.

AGRESTI, A. \& KATERI, M. 2011. Categorical data analysis, Springer.

ALAKUKKU, L., RISTOLAINEN, A. \& SALO, T. 2009. Grain yield and nutrient balance of spring cereals in different tillage systems. Proc. 18th 1331 ISTRO Conf., Izmir, Turkey, Paper T6-005, pp. 1-7.

ARVIDSSON, J., ETANA, A. \& RYDBERG, T. 2014. Crop yield in Swedish experiments with shallow tillage and no-tillage 1983-2012. European journal of agronomy, 52, 307-315.

BAILEY, K. \& DUCZEK, L. 1996. Managing cereal diseases under reduced tillage. Canadian Journal of Plant Pathology, 18, 159-167. 
BALL, B. Reduced tillage in Great Britain: practical and research experience. EC Workshop: Agriculture: Energy Saving by Reduced Soil Tillage, Gottingen, Luxembourg: Commission of the European Communities, 1987. 10-11.

BELL, M. M. 2010. Farming for us all: Practical agriculture and the cultivation of sustainability, Penn State press.

BEWICK, V., CHEEK, L. \& BALL, J. 2005. Statistics review 14: Logistic regression. Critical Care, 9, 112.

BITSCH, V. 2005. Qualitative research: A grounded theory example and evaluation criteria. Journal of Agribusiness, 23, 75-91.

BOSSANGE, A. V., KNUDSON, K. M., SHRESTHA, A., HARBEN, R. \& MITCHELL, J. P. 2016. The Potential for Conservation Tillage Adoption in the San Joaquin Valley, California: A Qualitative Study of Farmer Perspectives and Opportunities for Extension. PloS one, 11, e0167612.

BULLOCK, J. 2004. Benefits, challenges and pitfalls of alternative cultivation systems. In: Anon. (Eds.), Managing Soil and Roots for Profitable Production: Focusing on the Agronomic, Environmental and Economic Impact of Cultivation Systems and Establishment Methods. Home Grown Cereals Authority, London, pp. 8.1-8.6.

BULTENA, G. L. \& HOIBERG, E. O. 1983. Factors affecting farmers' adoption of conservation tillage. Journal of Soil and Water Conservation, 38, 281-284.

CANNELL, R. 1985. Reduced tillage in north-west Europe - a review. Soil and Tillage Research, 5, 129-177.

CARTER, A., JORDAN, V. \& STRIDE, C. 2003. A guide to managing crop establishment. Soil Management Initiative, Chester. 
CARTER, M. 1994. A review of conservation tillage strategies for humid temperate regions. Soil and Tillage Research, 31, 289-301.

CARTER, M. R. 2017. Conservation tillage in temperate agroecosystems. CRC Press.

CARTER, S. 2001. Multiple business ownership in the farm sector-Differentiating monoactive, diversified and portfolio enterprises. International Journal of Entrepreneurial Behavior \& Research, 7, 43-59.

COHEN, J., COHEN, P., WEST, S. G. \& AIKEN, L. S. 2013. Applied multiple regression/correlation analysis for the behavioral sciences, Routledge.

CONWAY, K. E. 1996. An overview of the influence of sustainable agricultural systems on plant diseases. Crop protection, 15, 223-228.

COUGHENOUR, C. M. \& CHAMALA, S. 2007. Conservation tillage and cropping innovation: constructing the new culture of agriculture, John Wiley \& Sons.

DAVIES, D. \& FINNEY, J. 2002a. Reduced cultivations for cereals: research, development and advisory needs under changing economic circumstances, Home Grown Cereals Authority.

DAVIES, D. B. \& FINNEY, J. B. 2002b. Reduced cultivations for cereals: research, development and advisory needs under changing economic circumstances, Home Grown Cereals Authority.

DE VITA, P., DI PAOLO, E., FECONDO, G., DI FONZO, N. \& PISANTE, M. 2007. Notillage and conventional tillage effects on durum wheat yield, grain quality and soil moisture content in southern Italy. Soil and Tillage Research, 92, 69-78.

DEFRA 2010. Farm Practices Survey 2010 - England. Available at: http://www.fao.org/fileadmin/templates/ess/ess_test_folder/World_Census_Agricultur 
e/Country_info_2010/Reports/Reports_2/UK_ENG_REPc_2010.pdf; accessed 22/03/2017. .

DERPSCH, R. \& FRIEDRICH, T. 2009. Global overview of conservation agriculture adoption,. Proceedings of the 4th World Congress on Conservation Agriculture, 4-7 February 2009, New Delhi, India, 429-438.

DILLMAN, D. A., SMYTH, J. D. \& CHRISTIAN, L. M. 2014. Internet, phone, mail, and mixed-mode surveys: the tailored design method. John Wiley \& Sons.

DILLMAN, D. A., SMYTH, J. D. \& MELANI, L. 2011. Internet, mail, and mixed-mode surveys: the tailored design method, JSTOR.

ECAF 2017. Uptake of conservation agriculture in Europe. Online http://www.ecaf.org/cain-europe/uptake-of-ca-in-europe accessed on 22/12/2017.

ECKERT, E. \& BELL, A. 2005. Invisible force: Farmers' mental models and how they influence learning and actions. Journal of Extension.

EL TITI, A. 2002. Soil tillage in agroecosystems, CRC press.

ENGLE, R. F. 1984. Wald, likelihood ratio, and Lagrange multiplier tests in econometrics. Handbook of econometrics, 2, 775-826.

EUROSTAT 2013. Agri-environmental indicator - tillage practices. AEI 11.2 fact sheet. Available at: http://ec.europa.eu/eurostat/statisticsexplained/index.php/Agrienvironmental_indicator_-_tillage_practices; accessed 22/3/2017.

FAROOQ, M. \& SIDDIQUE, K. H. 2015. Conservation agriculture: concepts, brief history, and impacts on agricultural systems. Conservation Agriculture. Springer.

FEDER, G. \& UMALI, D. L. 1993. The adoption of agricultural innovations: a review. Technological forecasting and social change, 43, 215-239. 
FLEMING, A. \& VANCLAY, F. 2009. Using discourse analysis to improve extension practice. Extension Farming Systems Journal, 5, 1.

FROUD-WILLIAMS, R., CHANCELLOR, R. \& DRENNAN, D. 1983a. Influence of cultivation regime upon buried weed seeds in arable cropping systems. Journal of Applied Ecology, 199-208.

FROUD-WILLIAMS, R., CHANCELLOR, R. \& DRENNAN, D. 1984. The effects of seed burial and soil disturbance on emergence and survival of arable weeds in relation to minimal cultivation. Journal of Applied Ecology, 629-641.

FROUD-WILLIAMS, R., DRENNAN, D. \& CHANCELLOR, R. 1983b. Influence of cultivation regime on weed floras of arable cropping systems. Journal of Applied Ecology, 187-197.

GILLER, K. E., WITTER, E., CORBEELS, M. \& TITTONELL, P. 2009. Conservation agriculture and smallholder farming in Africa: the heretics' view. Field crops research, 114, 23-34.

GRAHAM, J., ELLIS, F., CHRISTIAN, D. \& CANNELL, R. 1986. Effects of straw residues on the establishment, growth and yield of autumn-sown cereals. Journal of Agricultural Engineering Research, 33, 39-49.

GREENE, W. H. 2000. Econometric analysis (International edition).

HAN, Q., SIDDIQUE, K. \& LI, F. 2018. Adoption of Conservation Tillage on the Semi-Arid Loess Plateau of Northwest China. . Sustainability, 10(8), p.2621.

HEAP, I. 2014. Herbicide resistant weeds. Integrated pest management. Springer.

HEAP, I. \& DUKE, S. O. 2018. Overview of glyphosate- resistant weeds worldwide Pest management science, 74, pp.1040-1049. 
HOLLAND, J. 2004. The environmental consequences of adopting conservation tillage in Europe: reviewing the evidence. Agriculture, Ecosystems \& Environment, 103, 1-25.

HYDBOM, ALKAN OLSSON J \& PA, O. 2018. The use of conservation tillage in an agrointensive region: results from a survey of farmers in Scania, Sweden. Renewable Agriculture and Food Systems 1-10.

INGRAM, J. 2010. Technical and social dimensions of farmer learning: an analysis of the emergence of reduced tillage systems in England. Journal of Sustainable Agriculture, , 34(2) pp.183-201.

INGRAM, J., MILLS, J., DIBARI, C., FERRISE, R., GHALEY, B. B., HANSEN, J. G., IGLESIAS, A., KARACZUN, Z., MCVITTIE, A., MERANTE, P. \& MOLNAR, A. 2016. Communicating soil carbon science to farmers: incorporating credibility, salience and legitimacy. . Journal of rural studies, 115-128.

KASSAM, A., FRIEDRICH, T., DERPSCH, R., LAHMAR, R., MRABET, R., BASCH, G., GONZÁLEZ-SÁNCHEZ, E. J. \& SERRAJ, R. 2012. Conservation agriculture in the dry Mediterranean climate. Field Crops Research, 132, 7-17.

KASSAM, A., FRIEDRICH, T., SHAXSON, F. \& PRETTY, J. 2009. The spread of conservation agriculture: justification, sustainability and uptake. International journal of agricultural sustainability, 7, pp.292-320.

KNIGHT, S. Plough, Minimal Till or Direct Drill? Establishment Method and Production Efficiency. HGCA conference, 2004.

KRAUSE, M. A. \& BLACK, J. R. 1995. Optimal adoption strategies for no-till technology in Michigan. Review of Agricultural Economics, 299-310.

LAHMAR, R. 2010. Adoption of conservation agriculture in Europe: lessons of the KASSA project. Land use policy, 27, 4-10. 
LAMBERT, D., SULLIVAN, P., CLAASSEN, R. \& FOREMAN, L. 2012. Conservationcompatible Practices and Programs: Who Participates?, BiblioGov.

LOBLEY, M. \& BUTLER, A. 2010. The impact of CAP reform on farmers' plans for the future: Some evidence from South West England. Food Policy, 35, 341-348.

LUTMAN, P., MOSS, S., COOK, S. \& WELHAM, S. 2013. A review of the effects of crop agronomy on the management of A lopecurus myosuroides. Weed Research, 53, 299313.

MANGALASSERY, S., SJÖGERSTEN, S., SPARKES, D. \& MOONEY, S. 2015. Examining the potential for climate change mitigation from zero tillage. The Journal of Agricultural Science, 153, 1151-1173.

MARR, E. J. \& HOWLEY, P. 2019. The accidental environmentalists: Factors affecting farmers' adoption of pro-environmental activities in England and Ontario. Journal of Rural Studies.

MATTISON, E. H. \& NORRIS, K. 2007. Intentions of UK farmers toward biofuel crop production: implications for policy targets and land use change. ACS Publications.

MELANDER, B., MUNIER-JOLAIN, N., CHARLES, R., WIRTH, J., SCHWARZ, J., VAN DER WEIDE, R., BONIN, L., JENSEN, P. K. \& KUDSK, P. 2013. European perspectives on the adoption of nonchemical weed management in reduced-tillage systems for arable crops. Weed Technology, 27, 231-240.

MILLS, J., REED, M., SKAALSVEEN, K. \& INGRAM, J. 2019. The use of Twitter for sustainable soil management knowledge exchange. Soil Use and Management, 35, 195-203. 
MORRIS, J., MILLS, J. \& CRAWFORD, I. 2000. Promoting farmer uptake of agrienvironment schemes: the Countryside Stewardship Arable Options Scheme. Land Use Policy, 17, 241-254.

MORRIS, N., MILLER, P., ORSON, J. \& FROUD-WILLIAMS, R. 2010. The adoption of non-inversion tillage systems in the United Kingdom and the agronomic impact on soil, crops and the environment-A review. Soil and Tillage Research, 108, 1-15.

MOSS, S. R., PERRYMAN, S. A. \& TATNELL, L. V. 2007. Managing herbicide-resistant blackgrass (Alopecurus myosuroides): theory and practice. Weed Technology, 21, 300-309.

NOWAK, P. 1992. Why farmers adopt production technology Overcoming impediments to adoption of crop residue management techniques will be crucial to implementation of conservation compliance plans. Journal of Soil and Water Conservation, 47, 14-16.

PANNELL, D. J., MARSHALL, G. R., BARR, N., CURTIS, A., VANCLAY, F. \& WILKINSON, R. 2006. Understanding and promoting adoption of conservation practices by rural landholders. Animal Production Science, 46, 1407-1424.

PANNELL, D. J., MARSHALL, G. R., BARR, N., CURTIS, A., VANCLAY, F. \& WILKINSON, R. 2011. Understanding and promoting adoption of conservation practices by rural landholders. Changing Land Management: Adoption of New Practices by Rural Landholders, 11.

PAPPA, E., KOUTSOURIS, A., INGRAM, J., DEBRUYNE, L., COOREMAN, H. \& MARCHAND, F. 2018. Structural aspects of on-farm demonstrations: Key considerations in the planning and design process. . In 13th European International Farming Systems Association (IFSA) Symposium, Farming systems: facing 
uncertainties and enhancing opportunities, 1-5 July 2018, Chania, Crete, Greece (pp. 1-13). International Farming Systems Association (IFSA) Europe.

PENNINGS, J. M., IRWIN, S. H. \& GOOD, D. L. 2002. Surveying farmers: A case study. Review of agricultural economics, 24, 266-277.

PIMENTEL, D., HARVEY, C., RESOSUDARMO, P. \& SINCLAIR, K. 1995. Environmental and economic costs of soil erosion and conservation benefits. Science, 267, 1117.

POWLSON, D., BHOGAL, A., CHAMBERS, B., COLEMAN, K., MACDONALD, A., GOULDING, K. \& WHITMORE, A. 2012. The potential to increase soil carbon stocks through reduced tillage or organic material additions in England and Wales: a case study. Agriculture, Ecosystems \& Environment, 146, 23-33.

POWLSON, D. S., STIRLING, C. M., JAT, M., GERARD, B. G., PALM, C. A., SANCHEZ, P. A. \& CASSMAN, K. G. 2014. Limited potential of no-till agriculture for climate change mitigation. Nature Climate Change, 4, 678-683.

PROKOPY, L. S., FLORESS, K., KLOTTHOR-WEINKAUF, D. \& BAUMGART-GETZ, A. 2008. Determinants of agricultural best management practice adoption: evidence from the literature. Journal of Soil and Water Conservation, 63, 300-311.

ROGERS, E. M. 1961. Characteristics of agricultural innovators and other adopter categories.

ROLING, N. G. \& WAGEMAKERS, M. A. E. 2000. Facilitating sustainable agriculture: participatory learning and adaptive management in times of environmental uncertainty, Cambridge University Press.

SKAALSVEEN, K., INGRAM, J. \& CLARKE, L. E. 2019. The effect of no-till farming on the soil functions of water purification and retention in north-western Europe: A literature review. Soil and Tillage Research, 189, 98-109. 
SOANE, B. D., BALL, B. C., ARVIDSSON, J., BASCH, G., MORENO, F. \& ROGERESTRADE, J. 2012. No-till in northern, western and south-western Europe: a review of problems and opportunities for crop production and the environment. Soil and Tillage Research, 118, 66-87.

SWINTON, S. M., RECTOR, N., ROBERTSON, G. P., JOLEJOLE-FOREMAN, C. \& LUPI, F. 2015. Farmer decisions about adopting environmentally beneficial practices. The ecology of agricultural landscapes, 340-359.

TOWNSEND, J., R. S. \& P., W. 2016. How do we cultivate in England? Tillage practices in crop production systems. Soil Use and Management 32 (1). pp. 106-117. ISSN 14752743.

TOWNSEND, T., SPARKES, D., RAMSDEN, S., GLITHERO, N. \& WILSON, P. 2018. Wheat straw availability for bioenergy in England. Energy Policy, 122, 349-357.

VAN DEN PUTTE, A., GOVERS, G., DIELS, J., GILLIJNS, K. \& DEMUZERE, M. 2010. Assessing the effect of soil tillage on crop growth: a meta-regression analysis on European crop yields under conservation agriculture. European journal of agronomy, $33,231-241$.

VANCLAY, F. 2004. Social principles for agricultural extension to assist in the promotion of natural resource management. Animal Production Science, 44, 213-222.

VERCH, G., KÄCHELE, H., HÖLTL, K., RICHTER, C. \& FUCHS, C. 2009. Comparing the profitability of tillage methods in Northeast Germany-A field trial from 2002 to 2005. Soil and Tillage Research, 104, 16-21.

WAUTERS, E. \& MATHIJS, E. 2014. The adoption of farm level soil conservation practices in developed countries: A meta-analytic review. International journal of agricultural resources, governance and ecology., 10, pp.78-102. 


\section{Figure Captions}

Figure 1. Percentage of farmer responses by tillage practices undertaken on the farm; note that most farmers undertake more than one tillage practice and hence the sum of responses exceeds $100 \%$. B. Percentage of farmer respondents' land area covered by tillage practice.

Figure 2. Percentage response by: A. Farm size. B. Tillage practices by farm size. C. Farm type. D. Tillage practices by farm type. PL: ploughing, RT: reduced tillage (the sum NT (no-tillage) and MT (minimum-tillage)), and Mix (RT and PL practised at the same time). Note that for panel D most farmers undertake more than one tillage practice and hence the sum of responses exceeds $100 \%$.

Figure 3. Percentage responses by: A. GOR. B. EU super regions. C. Tillage practices by GOR. D. Tillage practices by EU super regions. PL: ploughing, RT: reduced tillage (the sum NT (no-tillage) and MT (minimumtillage)), and Mix (RT and PL practised at the same time).

Figure 4. Percentage responses by: A. Farmers' age (years). B. Tillage practices by farmers' age (years). C. Farmers' educational qualification. D. Tillage practices by farmers' educational qualification.

Figure 5. Farmers' responses (\%) regarding to the challenges of $\mathbf{A}$. minimum tillage practice and $\mathbf{B}$. no-tillage practice.

This article is protected by copyright. All rights reserved. 
Table 1. Number and percentages of farmers adopting different tillage practices.

\begin{tabular}{lll}
\hline Tillage system & Number of farms & $\%$ \\
\hline NT only & 2 & 0.54 \\
MT only & 27 & 7.28 \\
NT and MT & 14 & 3.77 \\
RT only (sum of NT only + MT only + NT and MT) & 43 & 11.59 \\
PL only & 114 & 30.73 \\
NT and PL & 14 & 3.77 \\
MT and PL & 164 & 44.2 \\
NT, MT and PL & 36 & 9.71 \\
Mixed of reduced tillage and ploughing (sum of NT & 214 & 57.68 \\
and PL + MT and PL + NT, MT and PL) & & \\
\hline
\end{tabular}

This article is protected by copyright. All rights reserved. 
Table 2. Chi-square test results showing the differences between RT adopters and non-adopters. RT: reduced tillage (the sum of NT (no-tillage) and MT (minimum-tillage)).

\begin{tabular}{|c|c|c|c|c|c|}
\hline Variables & Options & $\begin{array}{l}\text { Total } \\
\text { number of } \\
\text { farms (\%) }\end{array}$ & $\begin{array}{l}\text { Number of } \\
\text { farms using RT } \\
\text { compared to } \\
\text { whole sample } \\
\text { (\%) }\end{array}$ & $\begin{array}{l}\text { (\%) farms } \\
\text { using RT } \\
\text { within the } \\
\text { same } \\
\text { option } \\
\text { category }\end{array}$ & $\begin{array}{l}\text { Number of farms } \\
\text { using PL only } \\
\text { within the same } \\
\text { option category } \\
\text { (\%) }\end{array}$ \\
\hline \multirow{5}{*}{$\begin{array}{l}\text { Farm size } \\
\text { (ha) }\end{array}$} & $\leq 50$ & $22(6.06)$ & $7(2.8)$ & 31.82 & $15(68.18)$ \\
\hline & $50-100$ & $67(18.46)$ & $27(10.8)$ & 40.30 & $40(59.70)$ \\
\hline & $100-200$ & $98(27.00)$ & $59(23.6)$ & 60.20 & $39(39.80)$ \\
\hline & $200-400$ & $103(28.37)$ & $86(34.4)$ & 83.50 & $17(16.50)$ \\
\hline & $>400$ & $73(20.11)$ & $71(28.4)$ & 97.26 & $2(2.74)$ \\
\hline \multicolumn{2}{|l|}{$x^{2}$} & 363 & $250(P<0.001)$ & & \\
\hline \multirow[t]{4}{*}{ Farm type } & Combinable crops & $127(34.51)$ & $104(40.78)$ & 81.89 & $23(18.11)$ \\
\hline & General cropping & $57(15.49)$ & 39 (15.29) & 68.42 & $18(31.58)$ \\
\hline & Mixed (crops + livestock) & $164(44.57)$ & $107(41.96)$ & 65.24 & 57 (34.76) \\
\hline & Livestock & $20(5.43)$ & $5(1.96)$ & 25.00 & $15(75.00)$ \\
\hline \multicolumn{2}{|l|}{$x^{2}$} & 368 & $255(P<0.001)$ & & \\
\hline \multirow[t]{9}{*}{ GOR $^{1}$} & North east (1) & $16(4.42)$ & $12(4.76)$ & 75.00 & $4(25.00)$ \\
\hline & North West (2) & $9(2.49)$ & $2(0.79)$ & 22.22 & $7(77.78)$ \\
\hline & $\begin{array}{l}\text { Yorkshire and the } \\
\text { Humber (3) }\end{array}$ & $64(17.68)$ & $42(16.67)$ & 65.63 & $22(34.38)$ \\
\hline & East midlands (4) & $57(15.75)$ & $44(17.46)$ & 77.19 & $13(22.81)$ \\
\hline & West midlands (5) & $33(9.12)$ & $18(7.14)$ & 54.55 & $15(45.45)$ \\
\hline & East of England (6) & $84(23.20)$ & $67(26.59)$ & 79.76 & $17(20.24)$ \\
\hline & South east (8) & 47 (12.98) & 40 (15.87) & 85.11 & 7 (14.89) \\
\hline & South west (9) & $52(14.36)$ & $27(10.71)$ & 51.92 & $25(48.08)$ \\
\hline & & 362 & 252 & & \\
\hline \multicolumn{2}{|l|}{$x^{2}$} & & $(6,8,9) P<0.05$ & & \\
\hline \multirow[t]{3}{*}{ Region $^{2}$} & North & 89 (24.59) & $56(22.22)$ & 62.92 & $33(37.08)$ \\
\hline & East & 188 (51.93) & 151 (59.92) & 80.32 & 37 (19.68) \\
\hline & West & $85(23.48)$ & $45(17.86)$ & 52.94 & $40(47.06)$ \\
\hline \multirow[t]{2}{*}{$x^{2}$} & & 362 & 252 & & \\
\hline & & & $P<0.001$ & & \\
\hline
\end{tabular}

This article is protected by copyright. All rights reserved. 


$\begin{array}{llllll}\begin{array}{l}\text { Farmer } \\ \text { age (year) }\end{array} & <34 & 14(3.83) & 12(4.76) & 85.71 & 2(14.29) \\ & 35-44 & 32(8.74) & 26(10.32) & 81.25 & 6(18.75) \\ & 45-54 & 92(25.14) & 64(25.40) & 69.57 & 28(30.43) \\ & 55-64 & 126(34.43) & 87(34.52) & 69.05 & 39(30.95) \\ & 65-74 & 75(20.49) & 45(17.86) & 60.00 & 30(40.00) \\ \mathbf{X}^{2} & >75 & 27(7.38) & 18(7.14) & 66.67 & 9(33.33) \\ \text { Education } & \text { GCSE/A level/others } & 366 & 252(\mathrm{NS}) & & 65(45.77) \\ & \text { (N/A) } & 142(39.12) & 77(30.68) & 54.23 & 34(23.13) \\ & \text { Diploma } & 147(40.50) & 113(45.02) & 76.87 & 11(18.97) \\ \mathbf{X}^{2} & \text { BSC } & 58(15.98) & 47(18.73) & 81.03 & 2(12.50)\end{array}$

${ }^{1}$ GOR - Government Office Region

${ }^{2}$ European Union super region

This article is protected by copyright. All rights reserved. 
Table 3. Summary of the logit regression data.

\begin{tabular}{lllll}
\hline Variables & Observation & Mean (Standard Error) & Minimum & Maximum \\
\hline Reduce tillage & 334 & $69.46( \pm 46.13)$ & 0.00 & 100.00 \\
Farm size & 334 & $3.39( \pm 1.18)$ & 1.00 & 5.00 \\
GOR $^{1}$ & 334 & $5.43( \pm 2.32)$ & 1.00 & 9.00 \\
Farm type & 334 & $2.18( \pm 0.98)$ & 1.00 & 4.00 \\
Farm tenure & 334 & $2.00( \pm 0.94)$ & 1.00 & 3.00 \\
Age (year) & 334 & $58.08( \pm 12.00)$ & 30.00 & 80.00 \\
$\begin{array}{l}\text { Minimum } \\
\text { experience (year) }\end{array}$ & 334 & $24.73( \pm 11.54)$ & 5.00 & 40.00 \\
$\begin{array}{l}\text { Gender } \\
\text { Highest }\end{array}$ & 334 & $0.97( \pm 0.16)$ & 0.00 & 1.00 \\
education level & 334 & $1.85( \pm 0.85)$ & 1.00 & 5.00 \\
\hline
\end{tabular}

${ }^{1}$ Government Office Region

LR Chi-Squared $(29)=116.84$, Chi Squared test $P<0.001$, Log likelihood $=-6.38$, Pseudo $R^{2}=0.29$

This article is protected by copyright. All rights reserved. 
Table 4. The effects of different variables on the reduced tillage adoption using the odds ratio.

\begin{tabular}{|c|c|c|c|c|c|c|}
\hline Variables & & $\begin{array}{l}\text { Odds } \\
\text { Ratio }\end{array}$ & $\begin{array}{l}\text { Standard } \\
\text { Error }\end{array}$ & Wald /z/ & $P$ value & $\begin{array}{l}\text { [95\% Confidence } \\
\text { Interval] }\end{array}$ \\
\hline \multirow[t]{5}{*}{ Farm size } & $\leq 50$ ha & 1.00 & & & & \\
\hline & $50-100$ ha & 1.22 & 0.74 & 0.33 & 0.74 & $0.37,4.03$ \\
\hline & $100-200$ ha & 3.35 & 2.04 & 1.99 & 0.05 & $1.02,11.02$ \\
\hline & $200-400$ ha & 9.42 & 5.98 & 3.53 & $<0.001$ & $2.71,32.71$ \\
\hline & $>400$ ha & 47.04 & 43.67 & 4.15 & $<0.001$ & $7.63,290.17$ \\
\hline \multirow[t]{3}{*}{ GOR $^{1}$} & North east (1) & 1.00 & & & & \\
\hline & North West (2) & 0.24 & 0.27 & -1.24 & 0.22 & $0.02,2.32$ \\
\hline & $\begin{array}{l}\text { Yorkshire and the } \\
\text { Humber (3) }\end{array}$ & 0.69 & 0.52 & -0.5 & 0.62 & $0.16,3$ \\
\hline \multicolumn{7}{|l|}{ Region $^{2}$} \\
\hline & East England & 1 & & & & \\
\hline \multirow[t]{2}{*}{ Tenure } & North England & 0.76 & 0.63 & -0.33 & 0.75 & $0.15,3.89$ \\
\hline & West England & 0.54 & 0.33 & -1.01 & 0.32 & $0.16,1.79$ \\
\hline \multirow[t]{11}{*}{ Age (years) } & South east (8) & - & - & - & - & - \\
\hline & South west (9) & - & - & - & - & - \\
\hline & Own all land & 1 & & & & \\
\hline & Tenant & 1.06 & 0.5 & 0.12 & 0.91 & $0.42,2.67$ \\
\hline & Mixed & 1.77 & 0.61 & 1.65 & 0.1 & $0.9,3.5$ \\
\hline & $<34$ & 1 & & & & \\
\hline & $35-44$ & 1.16 & 1.36 & 0.13 & 0.9 & $0.12,11.46$ \\
\hline & $45-54$ & 0.44 & 0.49 & -0.74 & 0.46 & $0.05,3.8$ \\
\hline & $55-64$ & 0.59 & 0.67 & -0.47 & 0.64 & $0.06,5.54$ \\
\hline & $65-74$ & 0.38 & 0.46 & -0.8 & 0.43 & $0.04,4.05$ \\
\hline & $>75$ & 1.07 & 1.39 & 0.05 & 0.96 & $0.08,13.57$ \\
\hline \multirow[t]{2}{*}{ Experience } & Less than 10 & 1 & & & & \\
\hline & 10 years & 0.7 & 0.58 & -0.43 & 0.66 & $0.14,3.54$ \\
\hline
\end{tabular}

This article is protected by copyright. All rights reserved. 


$\begin{array}{llllll}20 \text { years } & 1.38 & 1.16 & 0.39 & 0.7 & 0.28,7.14 \\ 30 \text { years } & 1.25 & 1.13 & 0.25 & 0.8 & 0.22,7.29 \\ 40 \text { years } & 1.04 & 1.01 & 0.04 & 0.97 & 0.16,6.94\end{array}$

Gender $\quad$ Female

1

$\begin{array}{lllll}1.02 & 0.82 & 0.03 & 0.98 & 0.21,4.98\end{array}$

\begin{tabular}{|c|c|c|c|c|c|c|}
\hline \multirow[t]{4}{*}{ Education } & $\begin{array}{l}\text { GCSE A level or } \\
\text { equivalent / no } \\
\text { education }\end{array}$ & 1 & & & & \\
\hline & Diploma & 1.34 & 0.46 & 0.85 & 0.4 & $0.68,2.64$ \\
\hline & BSc degree & 1.74 & 0.9 & 1.08 & 0.28 & $0.63,4.79$ \\
\hline & MSc & 1.36 & 1.36 & 0.31 & 0.76 & $0.19,9.63$ \\
\hline \multirow{6}{*}{ Farm type } & $\mathrm{PhD}$ & - & - & - & - & - \\
\hline & Combinable crops & 1 & & & & \\
\hline & General cropping & 0.39 & 0.19 & -1.93 & 0.05 & $0.15,1.02$ \\
\hline & \multicolumn{6}{|l|}{ Mixed (crops and } \\
\hline & livestock) & 0.40 & 0.15 & -2.43 & 0.02 & $0.19,0.84$ \\
\hline & Livestock & 0.09 & 0.0799 & -2.79 & 0.01 & $0.02,0.5$ \\
\hline
\end{tabular}

${ }^{1}$ GOR - Government Office Region

${ }^{2}$ European Union super region

This article is protected by copyright. All rights reserved. 
Table 5. Factors influencing farmers' decision whether to plough or not.

\begin{tabular}{llll}
\hline Variables & $\begin{array}{l}\text { Not important at all/not } \\
\text { important/NA }\end{array}$ & Neutral & Important/Very important \\
\hline Prominent soil type & 0.97 & 16.75 & 72.25 \\
Weeds & 25.97 & 36.25 & 62.78 \\
Weather & 61.65 & 23.05 & 50.97 \\
Labour availability & 30.94 & 33.53 & 44.12 \\
Soil organic matter & 26.14 & 40.72 & 42.51 \\
Water availability & 19.08 & 39.31 & 41.62 \\
Machine availability & 22.35 & 35.80 & 38.07 \\
Crop varieties & 10.99 & 38.67 & 30.39 \\
Soil nutrients & 23.84 & 54.07 & 22.09 \\
Climate change & 16.77 & 29.32 & 9.02 \\
\hline
\end{tabular}

This article is protected by copyright. All rights reserved. 

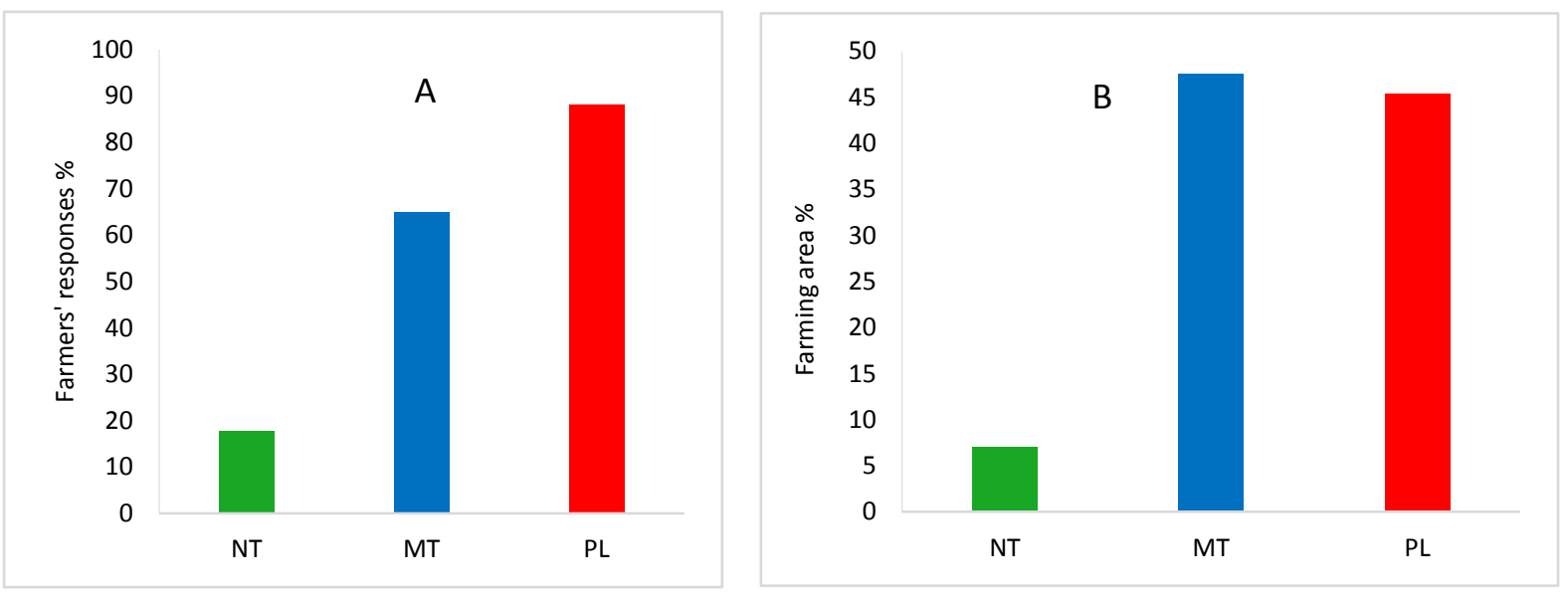

Figure 1. Percentage of farmer responses by tillage practices undertaken on the farm; note that most farmers undertake more than one tillage practice and hence the sum of responses exceeds $100 \%$. B. Percentage of farmer respondents' land area covered by tillage practice.

This article is protected by copyright. All rights reserved. 

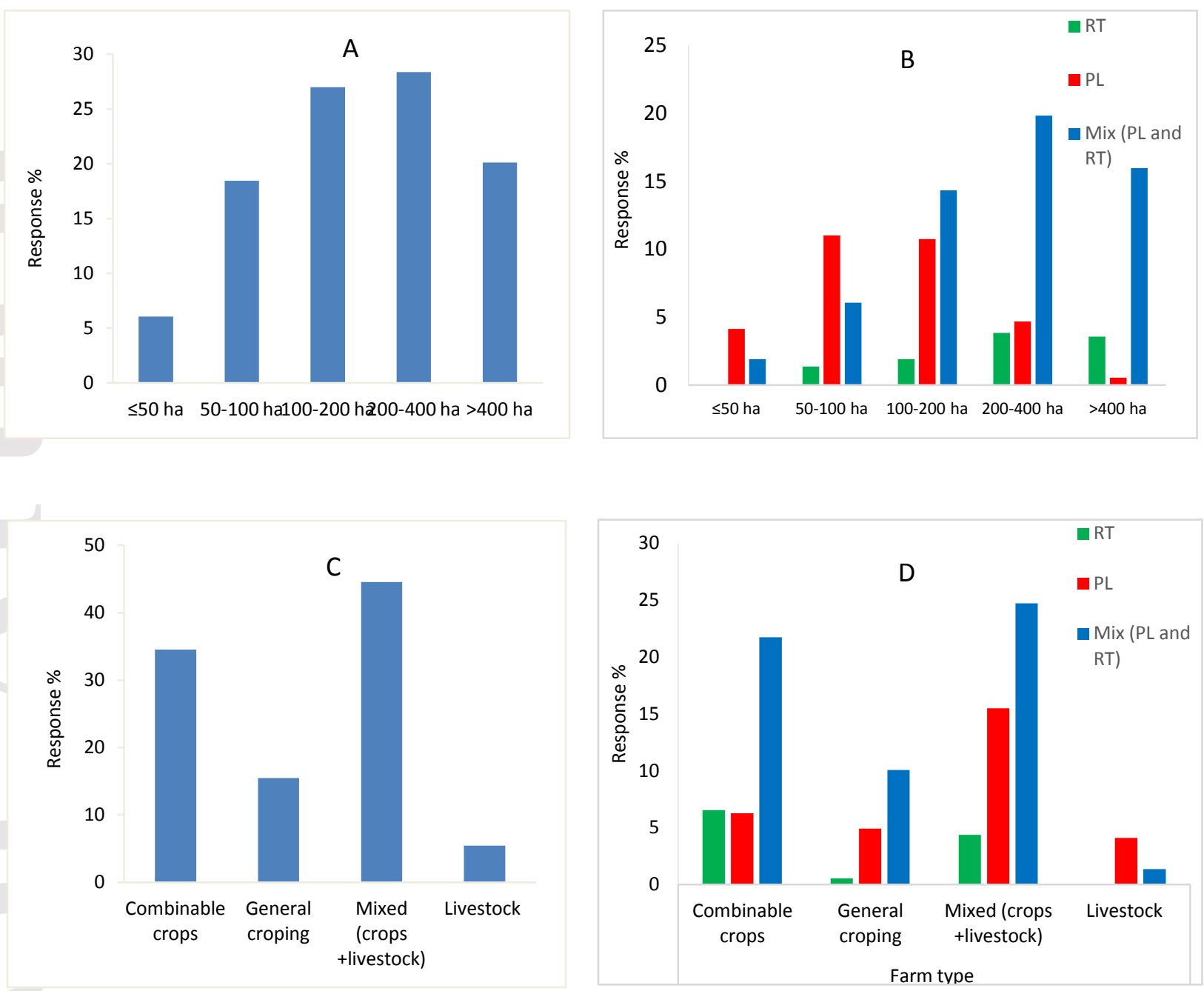

Figure 2. Percentage response by: A. Farm size. B. Tillage practices by farm size. C. Farm type. D. Tillage practices by farm type. PL: ploughing, RT: reduced tillage (the sum NT (no-tillage) and MT (minimum-tillage)), and Mix (RT and PL practised at the same time). Note that for panel D most farmers undertake more than one tillage practice and hence the sum of responses exceeds $100 \%$. 

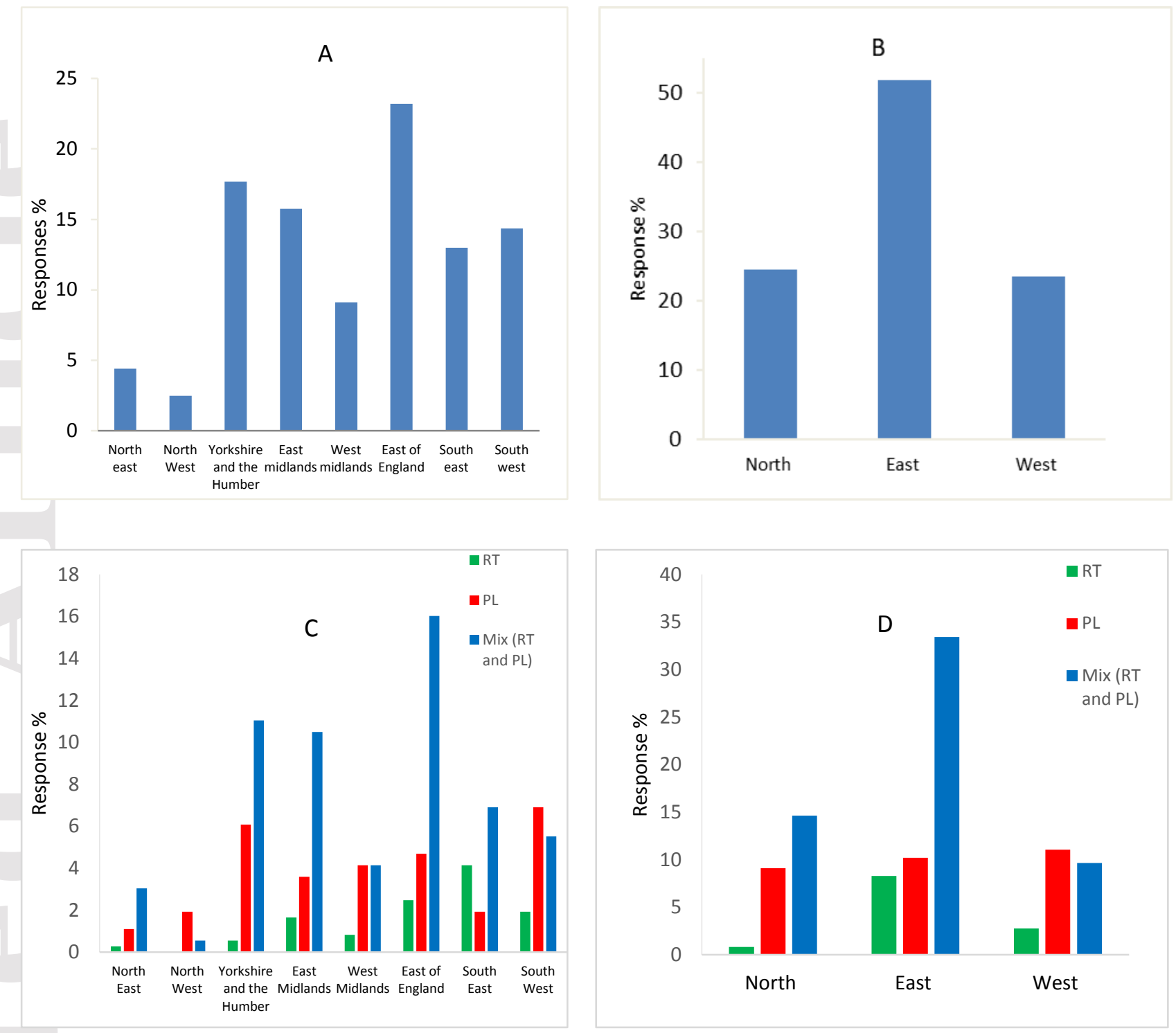

Figure 3. Percentage responses by: A. GOR. B. EU super regions. C. Tillage practices by GOR. D. Tillage practices by EU super regions. PL: ploughing, RT: reduced tillage (the sum NT (no-tillage) and MT (minimum-tillage)), and Mix (RT and PL practised at the same time). 

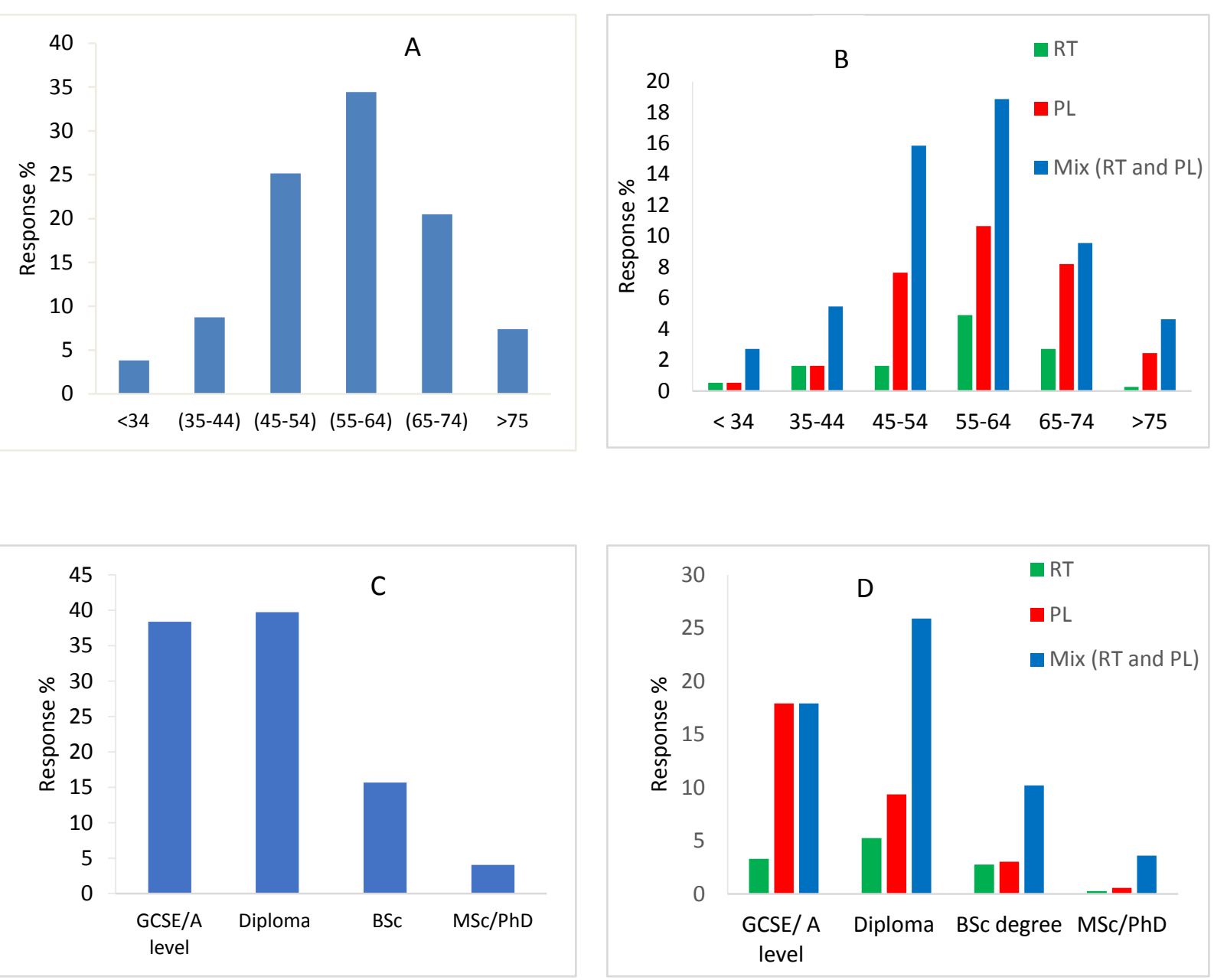

Figure 4. Percentage responses by: A. Farmers' age (years). B. Tillage practices by farmers' age (years). C. Farmers' educational qualification. D. Tillage practices by farmers' educational qualification. 

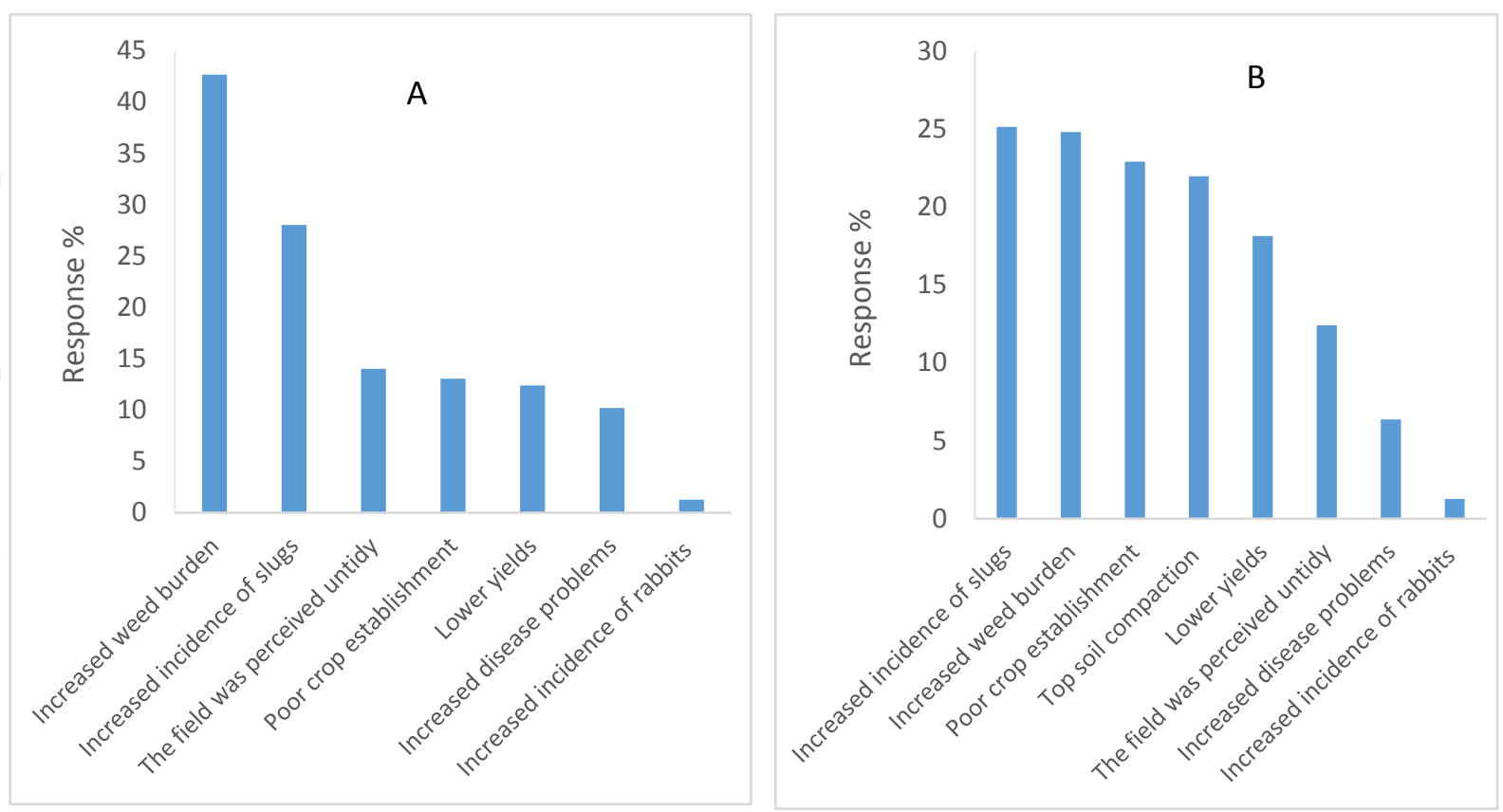

Figure 5. Farmers' responses (\%) regarding to the challenges of A. minimum tillage practice and B. no-tillage practice.

This article is protected by copyright. All rights reserved. 